\title{
A Process-Oriented Framework of Competencies for Sustainability Entrepreneurship
}

\author{
Tamsin Foucrier ${ }^{1, *}$ and Arnim Wiek ${ }^{1,2}$ \\ 1 School of Sustainability, Arizona State University, Tempe, AZ 85281, USA; arnim.wiek@asu.edu \\ 2 Center for Global Sustainability and Cultural Transformation, Leuphana University of Lüneburg, \\ D-21335 Lüneburg, Germany \\ * Correspondence: tamsin.connell@asu.edu
}

Received: 7 August 2019; Accepted: 9 November 2019; Published: 17 December 2019

\begin{abstract}
Employee-owned businesses, benefit corporations, and other efforts in sustainability entrepreneurship are responding to prevalent challenges such as climate change, economic inequalities, and unethical business behavior. Universities, however, often fall short in sufficiently equipping students with competencies in sustainability entrepreneurship. One reason is that none of the existing frameworks links competencies to the actual processes of entrepreneurship, from discovery to consolidation. If graduates are to successfully start and run sustainability-oriented enterprises, the real-world entrepreneurship processes should provide the main orientation for training and learning. The present study proposes such a framework. We first conducted a qualitative literature review on competencies for entrepreneurs, sustainability professionals, social entrepreneurs, and sustainability entrepreneurs. We clustered the identified competencies according to conceptual similarities. On this basis, we describe sustainability entrepreneurship competencies along the entrepreneurial process model. The result is a process-oriented and literature-based framework of sustainability entrepreneurship competencies. It is intended to be used as a general vision for students, faculty, and entrepreneurs, as well as for the design of curricula, courses, and assessments.
\end{abstract}

Keywords: transformational sustainability; sustainability competencies; curriculum design; business education

\section{Introduction}

Employee-owned businesses, benefit corporations, and local living economies counter business-as-usual practices by sourcing ingredients and materials locally, producing goods in zero-waste facilities powered by renewable energy, and by offering robust employee benefits and well-being programs, among others. These practices are examples of comprehensive or transformational sustainability entrepreneurship, driven by the vision of empowering the workforce and community, as well as developing products and services that not only minimize the impacts on the social and ecological systems we depend on, but actually improve them [1,2]. Sustainability entrepreneurship fosters business activities that do not exceed critical thresholds while supporting recovery and regeneration in environmental and social systems. Such entrepreneurship also challenge conventional ownership and management structures. For example, the King Arthur Flour Company is a certified B-Corp with a strong environmental performance while providing avenues of empowerment through $100 \%$ employee-ownership and employee volunteering programs. Or, the Grenada Chocolate Company empowers organic community farms and pioneers zero-emission distribution systems using solar power and sailboats to export their products.

While sustainability entrepreneurship is on the rise, universities and colleges around the world, however, provide few structures to support this trend. From management programs to business 
accelerators, the majority of offerings in higher education reproduce business-as-usual with the well-known flaws and shortcomings [3-7]. A recent survey of Canadian MBA programs revealed that students get exposed to Corporate Social Responsibility and related topics, but they are "not graduating with key competencies for sustainability" [8] (pp. 93-114). These attempts cover sustainability only as an addendum to conventional business education and perpetuate the "rhetoric" (vs. reality) of responsible management education [3]. Hence, scholars have advocated for comprehensive or transformational approaches that explore the knowledge, skills, and attitudes that entrepreneurs and business practitioners need to develop truly sustainable enterprises [2,9]. As Dyllik [4] (p. 16) states: "In the light of the pressing economic, social and environmental crises the world is facing, the feeling is spreading that not only business and economics but business schools also need to change fundamentally, if they want to be a provider of solutions to these crises and thereby keep and regain their legitimacy."

In response to these needs, a number of scholars have developed diverse competency frameworks for sustainability entrepreneurship [10-15]. They all offer valuable options but as a whole, they have two shortcomings. First, none of them links competencies to the actual processes of entrepreneurship (from initial discovery through planning, start-up, and build-out to consolidation and harvesting) [16-22]; a shortcoming that has been observed about competency frameworks in general [23]. Yet, if graduates are to successfully start and run sustainability-oriented enterprises, the real-world entrepreneurship processes should provide the main orientation for training and learning. Second, the ones that are more practically oriented, however, do not rely on and synthesize the competencies already presented in the literature. This has led to competency frameworks guiding curriculum and course development that are somewhat disconnected from the reality of entrepreneurship and/or lack building bridges across the different disciplines related to entrepreneurship.

Against this background, we present the results of a study that addresses the research question: What competencies, according to a broad range of literature, do entrepreneurs need when starting and running enterprises that contribute to sustainability transformations? Considering the fairly small but rich sample of relevant literature, we conducted a qualitative review of the literature on competencies for entrepreneurs, sustainability professionals, social entrepreneurs, and sustainability entrepreneurs-then clustered the identified competencies according to conceptual similarities. On this basis, we propose a framework of sustainability entrepreneurship competencies along an entrepreneurial process model, describing each process phase with associated tasks and competencies.

The result of this study is a process-oriented and literature-based framework of sustainability entrepreneurship competencies. It is intended to be used as a general vision for students, faculty, and entrepreneurs, as well as for the design of curricula, courses, and assessments.

\section{The Landscape of Competency Frameworks}

The first relevant body of literature is on entrepreneurship education, which has experienced a rise in the last 10 years [24]. This literature focuses on enabling entrepreneurs to recognize opportunities for creative destruction, identify and acquire resources, cope with uncertainty, overcome obstacles, launch new ventures, create and maintain strong networks [25]. However, competencies necessary for sustainability entrepreneurship are not sufficiently addressed. Students are predominantly trained to assess opportunity against profits, without considering social and environmental impacts. Value creation as a competency focuses on maximizing returns for shareholders and investors with little explicit consideration of value creation for employees. Entrepreneurship education can equip students with the necessary competencies for "weak sustainability" referring to "profit-normative businesses" that focus on environmental compliance or sustainability as a tool for increasing profits $[26,27]$ (pp. 3-28). However, for developing students' competencies in "strong/transformational" sustainability, i.e., being able to create "positive environmental, social, and economic value" [1] (pp. 1-2), "thereby sustaining the possibility that human and other life can flourish on this planet forever" [26] (pp. 97-123), the offered set of competencies needs revisions and expansion. 
The second relevant body of literature for developing a literature-based framework for sustainability entrepreneurship competencies is general sustainability education literature. This stream of literature rests on the assumption that professionals who deeply address sustainability in their work need to develop particular sets of competencies that adequately reflect and prepare them for working in an age of transformation [28]. Such competencies have been described, independent from any specific disciplinary background, as key competencies in sustainability problem-solving [28-32]. This framework integrates system thinking, future thinking, value thinking, strategic thinking, and interpersonal/professional skills in order to successfully contribute to sustainability transformations. While these competencies can be used as a base to define skills and knowledge sustainability entrepreneurs need, this framework is not specific enough. Sustainability entrepreneurship competencies should specifically enable entrepreneurs to identify, evaluate, and realize business opportunities that positively contribute to sustainable development [33].

The third relevant body of literature is on competencies for social entrepreneurship. This stream of literature identifies cognitive skills such as creative thinking, negotiation, leadership, and innovation [34] as well as competencies to market the organization, create significant social impact, and communicate with stakeholders as key for social entrepreneurs [2]. While this approach to entrepreneurship education moves a student closer to developing their competencies for sustainability entrepreneurship, it often fails to consider the environmental dimension of sustainability in business. While these competencies can be linked to the key competencies in sustainability (for example, stakeholder communication and interpersonal competence, ability to market the organization and strategic competence), social entrepreneurs ought to be able to balance social value creation with financially driven goals, i.e., the double bottom line [35].

The fourth relevant body of literature is frameworks for sustainability entrepreneurship competencies. Lans et al. [11,14], as an exemplary contribution in this category, base their framework on Wiek et al. [29], mentioned above. However, this framework, similar to others, is not functionally linked to what sustainability entrepreneurs do in practice. Also, if students are to be trained as the next leaders in employee-owned business, benefit corporations, local living economies, and so forth, competencies for sustainability entrepreneurship must focus on transformational knowledge and skills (e.g., knowledge of how to incorporate as an employee-owned business or a benefit corporation, if legislation exists).

The competency frameworks in all four streams of literature constitute a useful pool of skills and knowledge. Yet, they fall short in functionally linking these skills and knowledge sets to what sustainability entrepreneurs actually do when starting and running sustainability-oriented enterprises. In sum, (1) current sustainability competency frameworks need to be specified for sustainability entrepreneurship, (2) current entrepreneurship and social entrepreneurship competency frameworks need to be specified for sustainability entrepreneurship, and (3) current sustainability entrepreneurship competency frameworks need to be (a) specified for transformational sustainability entrepreneurship and (b) structured along the processes of sustainability entrepreneurship.

While drawing on these bodies of literature, this study provides a process-oriented model that articulates what a sustainability entrepreneur actually does over time and the competencies needed for this.

\section{Research Design}

Research is structured into three parts (Figure 1).

I. Qualitative Literature Review of Tasks: We identified, selected, and analyzed peer-reviewed and grey literature (including white papers and reports). Refereed work was identified through Google Scholar (the most extensive database for academic literature to date). In addition, we cross-checked with other databases and did not find any additional sources of relevance. Reports/white papers were identified through Google using the terms: "Sustainability", "Sustainability Entrepreneurship", "Social Entrepreneurship", “Social Enterprise”, “Competencies”, "Key Competencies", "Entrepreneurship", “Business Competencies", “Eco-business", “Corporate Social 
Responsibility", "Sustainability-driven Entrepreneurship", "Sustainability-driven Entrepreneurs", "Sustainable Entrepreneurship", "Entrepreneurship Education". The initial sample was cleaned up and the most relevant sources selected, using the following criteria: competencies sufficiently specified (knowledge/skills/attitudes); addresses competencies to run small-to-medium-sized enterprises (rather than to reform/transform existing enterprises); published in or after 2000 (last two decades); synthesis of exiting literature. The final pool entailed the following peer-reviewed articles and reports/white papers: Wiek et al. 2016 [1], Hesselbart \& Schaltegger 2014 [10], Lans et al. 2014 [11], Osagie et al. 2016 [12], Mindt \& Reickmann 2017 [13], Ploum et al. 2018 [14], Biberhofer et al. 2018 [15], Morris et al. 2013 [25], Wiek et al. 2011a [29], Willard et al. 2010 [32], Chell et al. 2007 [34], Miller et al. 2012 [35], Fantini et al. 2001 [36], Salgado et al. 2018 [37], Lans et al. 2011 [38], Mitchelmore et al. 2010 [39], Lambrechts et al. 2013 [40], Wu 2009 [41], Bernhardt et al. 2015 [42], Afshar et al. 2017 [43], Waldron 2016 [44], Moreau \& Mertens 2013 [45]. Each source was then analyzed, first, regarding entrepreneurial tasks.

I.

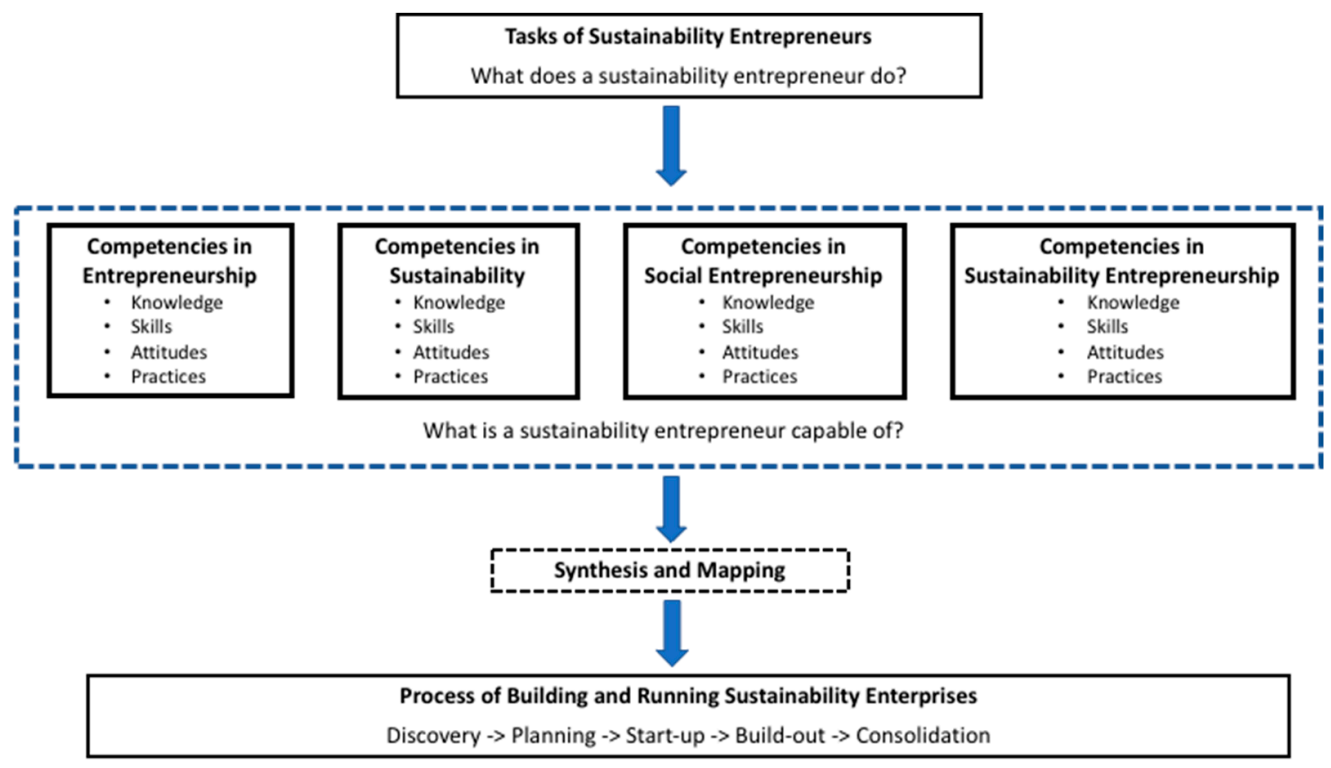

Figure 1. Overview of research design.

II. Qualitative Literature Review of Competencies: Each source was then analyzed with respect to competencies. We clustered the results according to conceptual similarities into four major competency groups: generic entrepreneurship competencies (knowledge, skills, attitudes, practices); generic sustainability competencies; social entrepreneurship competencies; and sustainability entrepreneurship competencies. The first cluster covers competencies that all entrepreneurs should be capable of, and thus, sustainability entrepreneurs, too. The second cluster covers competencies that all sustainability professionals should possess, and thus, sustainability entrepreneurs, too. The third cluster (social entrepreneurship competencies) was included because sustainability entrepreneurship grew out of the social entrepreneurship movement [33]. We delineate social entrepreneurship as a separate cluster to allow for identifying similarities and differences (not all social entrepreneurship competencies might be relevant for sustainability entrepreneurs). The final cluster (sustainability entrepreneurship competencies) accounts for literature that specifies sustainability competencies for entrepreneurs. The results were finally scanned for redundancies, cleaned-up, and synthesized.

III. Synthesis of Framework: A small set of guidelines was used to design the new competency framework to ensure applicability to curriculum and course design in sustainability entrepreneurship programs. The design guidelines were:

(a) Specifying and standardizing competencies from the literature to avoid generic descriptions or redundancies; 
(b) Bridging gaps in the literature (missing or insufficiently developed tasks or competencies);

(c) Using entrepreneurial practice-orientation (mapping out specific tasks and competencies) to avoid "laundry-listing" competencies;

(d) Using the key competencies in the sustainability framework [29] as a reference to provide a link to the ongoing competency discourse in various fields.

For the practice-orientation, we developed a simple entrepreneurial process model using insights from entrepreneurship literature [16-22] and from our literature review. For each phase, exemplary tasks were identified to indicate what an entrepreneur does in each phase. The identified tasks were then associated to competencies identified in the earlier parts.

\section{Results}

The synthesis of competencies for sustainability entrepreneurship starts off with a detailed look at the tasks sustainability entrepreneurs (ideally) perform (Section 4.1) and the corresponding competencies required to perform these tasks (Section 4.2). This serves as the basis for the new competency framework, which maps the identified tasks and competencies onto an ideal entrepreneurial process, from discovery and consolidation (Section 4.3).

\subsection{Tasks-What Sustainability Entrepreneurs Do}

The tasks are presented in four clusters (Table 1), as mentioned above (Section 3). At times, the reviewed literature identifies tasks and competencies with minor difference. For example, the task is defined as "marketing" and the competence is defined as "marketing skills". We tried to disentangle tasks and competencies. Tasks are actions that graduates should be able to perform (at the end of their training), while competencies are the associated knowledge, skills, attitudes, etc. they need to be capable of in order to perform these tasks. We aimed at spelling out this difference to a sufficient extent.

\subsection{Competencies-What Sustainability Entrepreneurs Are Capable of}

The competency compilation is presented in four clusters (Table 2), corresponding to the tasks identified above. As mentioned above (Section 4.1), we tried to separate tasks and competencies, without overly intervening in the presented concepts. Most of the reviewed literature pulls from generic sustainability competency frameworks [19,22,27], except for literature in Cluster I (entrepreneurs) and Cluster III (social entrepreneurs). Many of the identified competencies across all clusters are similar, for example, systems-thinking competence or teamworking skills (even if terminologies vary). This indicates convergence across streams of literature. For specifying sustainability entrepreneurship competencies, Cluster I provides valuable insights into business-specific competencies, for example, business plan development, financial auditing, accounting, etc.). While useful as a foundation for mapping out what sustainability entrepreneurs need to know and be capable of, the following lists do not integrate the competencies that complex sustainability entrepreneurship processes require. Such a framework is presented in the following section (Section 4.3), synthesizing the competencies listed below. 
Table 1. Tasks of sustainability entrepreneurs.

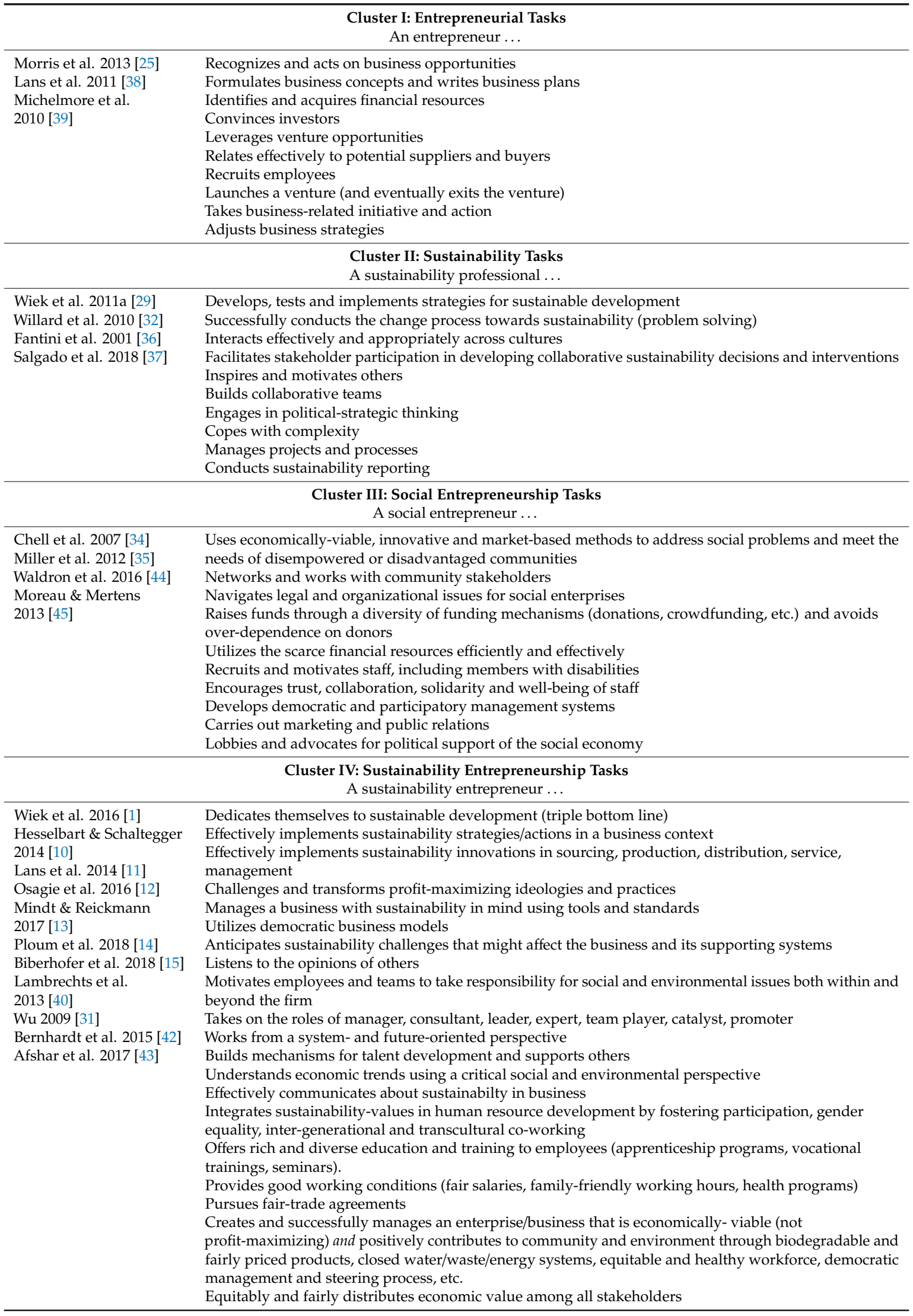


Table 2. Competencies relevant for sustainability entrepreneurs.

\begin{tabular}{|c|c|}
\hline \multicolumn{2}{|r|}{$\begin{array}{c}\text { Cluster I: Competencies of Entrepreneurs } \\
\text { An entrepreneur is ... }\end{array}$} \\
\hline $\begin{array}{l}\text { Morris et al. } 2013 \text { [25] } \\
\text { Lans et al. } 2011 \text { [38] } \\
\text { Michelmore et al. } \\
2010 \text { [39] }\end{array}$ & $\begin{array}{l}\text { Alert with respect to business opportunities/possesses entrepreneurial spirit/attitude } \\
\text { Able to anticipate and plan (imaginativeness) } \\
\text { Skilled in basic math and analytical reasoning } \\
\text { A leader, value-driven, mission-oriented, convincing } \\
\text { A "people person" with teamworking skills, communication skills, motivation skills, commitment skills, } \\
\text { delegation skills, coordination skills, ability to compromise } \\
\text { A resourceful person with high self-efficacy, self-management skills, perseverance }\end{array}$ \\
\hline \multicolumn{2}{|r|}{$\begin{array}{c}\text { Cluster II: Competencies of Sustainability Professionals } \\
\text { A sustainability professional possesses ... }\end{array}$} \\
\hline $\begin{array}{l}\text { Wiek et al. 2011a [29] } \\
\text { Willard et al. } 2010 \text { [32] } \\
\text { Fantini et al. } 2001 \text { [36] } \\
\text { Salgado et al. } 2018[37]\end{array}$ & $\begin{array}{l}\text { System-thinking competence } \\
\text { Future-thinking competence } \\
\text { Normative/Value competence } \\
\text { Strategic/Action competence } \\
\text { Interpersonal competence (including cultural and intercultural competence) } \\
\text { Integration competence }\end{array}$ \\
\hline \multicolumn{2}{|r|}{$\begin{array}{c}\text { Cluster III: Competencies of Social Entrepreneurs } \\
\text { A social entrepreneur is ... }\end{array}$} \\
\hline $\begin{array}{l}\text { Chell et al. } 2007 \text { [34] } \\
\text { Miller et al. } 2012 \text { [35] } \\
\text { Waldron et al. } 2016 \text { [44] } \\
\text { Moreau \& Mertens } \\
2013 \text { [45] }\end{array}$ & $\begin{array}{l}\text { Aware of and knowledgeable about social problems } \\
\text { Driven and inventive to create social impact, both within the enterprise and larger social and political } \\
\text { systems } \\
\text { Driven by values and criteria } \\
\text { Holding moral imperatives/ethics } \\
\text { Committed to a collective purpose } \\
\text { Able to lead and develop others } \\
\text { Skilled in recruiting people who are motivated to meet society's needs } \\
\text { Skilled in communicating complex messages in accessible ways } \\
\text { Skilled in resolving conflicts in democratic/participatory work environments } \\
\text { Willing to take risks } \\
\text { Innovative and creative } \\
\text { Skilled in basic math } \\
\text { Resourceful } \\
\text { Assertive but diplomatic }\end{array}$ \\
\hline \multicolumn{2}{|r|}{$\begin{array}{c}\text { Cluster IV: Competencies of Sustainability Entrepreneurs } \\
\text { A sustainability entrepreneur is ... }\end{array}$} \\
\hline $\begin{array}{l}\text { Wiek et al. 2016 [1] } \\
\text { Hesselbart \& Schaltegger } \\
2014 \text { [10] } \\
\text { Lans et al. 2014 [11] } \\
\text { Osagie et al. } 2016 \text { [12] } \\
\text { Mindt \& Reickmann } \\
2017 \text { [13] } \\
\text { Ploum et al. 2018 [14] } \\
\text { Biberhofer et al. 2018 [15] } \\
\text { Lambrechts et al. } \\
\text { 2013 [40] } \\
\text { Wu 2009 [41] } \\
\text { Bernhardt et al. 2015 [42] } \\
\text { Afshar et al. 2017 [43] }\end{array}$ & $\begin{array}{l}\text { Aware of and knowledgeable about sustainability problems } \\
\text { Able to think in economic systems such as circular economy, nexus of social/economic/environmental in } \\
\text { relation to business, local and regional economies, supply chains, etc. } \\
\text { Able to think in structured and creative ways about the future of his/her business and the supporting } \\
\text { systems with a sense for intergenerational justice and opportunity (e.g., in creating intergenerational } \\
\text { co-working spaces) } \\
\text { Able to think strategically and action-oriented by fostering a culture of failing, learning, critical thinking } \\
\text { Skilled in interpersonal competence (cooperative thinking skills, integrative leadership skills) } \\
\text { Socially competent (for building up, fostering, and capitalizing on personal networks, developing talent) } \\
\text { "Opportunistic" (in a good way) - being able to search for and pursue opportunities. } \\
\text { Able to think and act in structured/standardized ways (for managing, communicating, reporting, } \\
\text { evaluating) } \\
\text { Reflective (on personal experiences and views as well as broader, collective, reported experiences) } \\
\text { Committed to work towards a just world } \\
\text { Compassionate and loving }\end{array}$ \\
\hline
\end{tabular}

\subsection{A Process-Oriented Competency Framework for Sustainability Entrepreneurs}

We first identify a generic entrepreneurial process model from key entrepreneurial literature [16-22,46-48] and the literature analyzed before. This generic and iterative process model is comprised of five entrepreneurship phases (Discovery-Planning-Start-up-Build-out-Consolidation) and serves as the foundation for the competency framework (Figure 2). For each process phase, we identified main tasks and required specific competencies, both cross-referenced with literature sources [\#]. If gaps were observed, additions were made to items extracted from the referenced sources, or new items were added; additions are marked through an $[\mathrm{X}]$ in the tables below. To ensure continuity with the broader sustainability competency discourse, the relevant key competencies in sustainability [29] were indicated for each phase, too. Differences to conventional entrepreneurship are either more subtle or rather stark, depending on the item. For example, while conventional 
entrepreneurs might hire employees as qualified and available, sustainability entrepreneurs, driven by broad sustainability values, look to intentionally hire people from underrepresented groups who might need additional training, coaching, and mentoring. Or, while conventional entrepreneurs may be legally incorporated as a limited liability company (LLC), sustainability entrepreneurs, driven by broad sustainability values, look to intentionally be incorporated as a cooperative business or benefit corporation (as legislation permits).

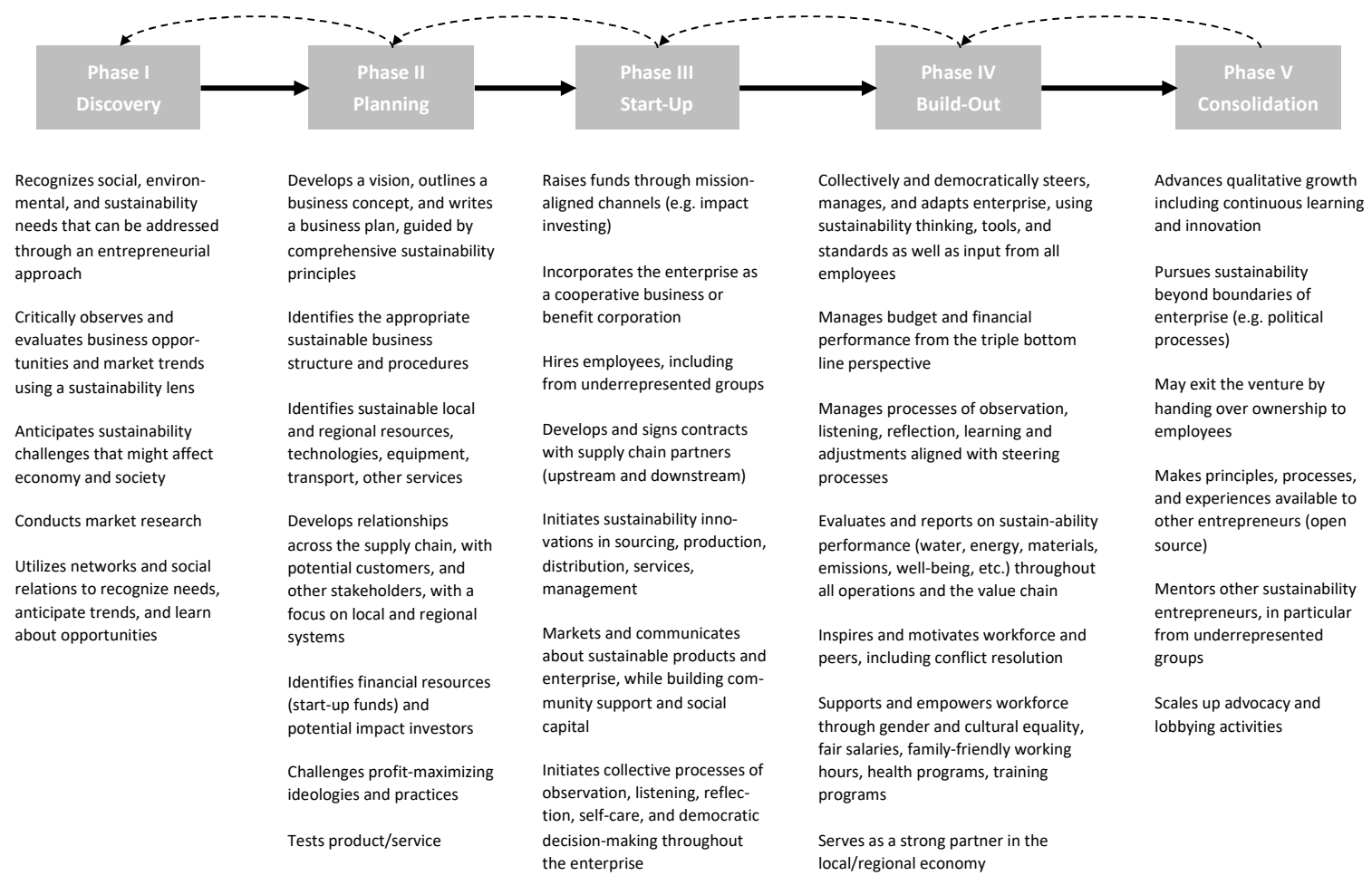

Figure 2. Overview of the iterative process of sustainability entrepreneurship with main tasks.

\subsubsection{Discovery Phase}

The discovery phase starts the process as sustainability entrepreneurs-driven by broad values and moral imperatives as well as personal and professional experiences-explore how to address specific social, environmental, and sustainability problems/needs through entrepreneurship (Table 3). Sustainability entrepreneurs make themselves familiar with these challenges, using system-thinking competence to identify upstream problem drivers and promising intervention points, as well as future-thinking competence to anticipate problems that might emerge in the future. They reflect on sustainability problems they might have encountered in their professional or personal lives using their "experience corridors" [46-48]. However, traditional business experience in training or employment might rather hold sustainability entrepreneurs back, while "experience corridors" with sustainability orientation-e.g., environmental advocacy experience or sustainable lifestyles—supports opportunity recognition in the discovery phase [49].

Problems and needs do not automatically translate into opportunities. Thus, sustainability entrepreneurs use their entrepreneurial alertness and spirit to critically observe and evaluate business opportunities that could be seized to address the identified problems/needs. This requires not only familiarity with the relevant economy sector or branch, but also specific market research to substantiate initial ideas and explorations. Interpersonal competence allows sustainability entrepreneurs to tap into various resources that support the outlined activities in the discovery phase. 
Table 3. Tasks and competencies in the discovery phase of sustainability entrepreneurship.

\begin{tabular}{|c|c|c|}
\hline Sustainability Entrepreneurship Tasks & $\begin{array}{c}\text { Sustainability Entrepreneurship } \\
\text { Competencies } \\
\text { (Knowledge/Skills/Attitudes) }\end{array}$ & $\begin{array}{l}\text { Sustainability } \\
\text { Competencies }\end{array}$ \\
\hline \multirow{2}{*}{$\begin{array}{l}\text { Recognizes social, environmental, and sustainability needs } \\
\text { that can be addressed through an entrepreneurial approach } \\
\text { from a systems perspective }[11,14,25,38,40] \\
\text { Critically observes and evaluates business opportunities and } \\
\text { market trends using a sustainability lens }[25,35,45] \\
\text { Anticipates sustainability challenges that might affect } \\
\text { economy and society }[29,37,39] \\
\text { Conducts market research [37] } \\
\text { Utilizes networks and social relations to recognize needs, } \\
\text { anticipates trends, and learn about opportunities [40-42] }\end{array}$} & $\begin{array}{l}\text { Knowledgeable about social, } \\
\text { environmental, and sustainability } \\
\text { problems }[15,35] \\
\text { Knowledgeable about relevant } \\
\text { economic sector and its history } \\
{[11,14,15,39,45]} \\
\text { Knowledgeable about } \\
\text { sustainability-oriented economy } \\
\text { and entrepreneurship models } \\
{[11,14,15,39,45]}\end{array}$ & \multirow[t]{2}{*}{$\begin{array}{l}\text { System-thinking competence; } \\
\text { Value-thinking competence; } \\
\text { Future-thinking competence; } \\
\text { Interpersonal competence }\end{array}$} \\
\hline & $\begin{array}{l}\text { Search skills }[15,25,38,42] \\
\text { Analytical skills [39] }\end{array}$ & \\
\hline
\end{tabular}

\subsubsection{Planning Phase}

During the planning phase, sustainability entrepreneurs develop visions for their enterprises, outline business concepts, and eventually write detailed business plans, guided by the bounded triple-bottom-line approach (Table 4). Some sustainability entrepreneurs might forgo a lengthy business plan development process and choose to focus on quickly developing and testing their "minimum viable product", guided by the "Lean Start-up" model [50]. In either case, these preparatory tasks require planning, numeracy, and analytical reasoning skills as well as system-thinking competence specific to economic systems (e.g., circular economy, supply chains). During the discovery phase, entrepreneurs may have been introduced to new business forms such as cooperatives, benefit corporations, or social enterprises. During the planning phase, entrepreneurs now intentionally "activate" that knowledge and identify a suitable business structure as well as explore sustainability procedures to be implemented (e.g., sustainability accounting). Business structures such as employee-owned businesses require skills that enable the sustainability entrepreneurs to effectively run and participate in democratically-controlled businesses. Familiarity with overarching frameworks such as the Sustainable Business Model Canvas [26] or the Framework for Strategic Sustainable Development [27] offers the opportunity to take comprehensive and systemic perspectives on the planned businesses. Sustainability entrepreneurs are committed to local and regional economies and thus strive to use sustainable (e.g., renewable) local and regional resources, technologies, equipment, transport, and other service options-which first need to be identified and then further specified together with suppliers, potential customers, and other stakeholders. Sustainable entrepreneurs participate in alternative financing and banking schemes, such as impact investments or the gift economy. In the planning stage, these options need to be identified, evaluated, and eventually selected. During these various activities, sustainability entrepreneurs need to find constructive ways to challenge profit-maximizing ideologies and practices. Various "people skills" help in navigating this contentious space and allow sustainability entrepreneurs to defend their positions in polite and nonetheless assertive ways, with the ability to compromise (on some issues) being a desirable skill. Sustainability entrepreneurs also adapt their communication strategies to account for differences in intention, target audience, etc. For example, a sustainability entrepreneur who has experience in an economic sector and aims to "innovate" within an existing field (e.g., technological innovation in the renewable energy sector) may present his/her value proposition as an incremental and inevitable progression, supported by a fact-based justification. On the other hand, a sustainability entrepreneur who may lack experience in a particular sector and aims at innovating beyond his/her sector of expertise (e.g., an employee-owned health service provider) may 
craft a message of a "noteworthy disruption" and may rely on moral arguments when engaging with relevant stakeholders or decision-makers [44].

Table 4. Tasks and competencies in the planning phase of sustainability entrepreneurship.

\begin{tabular}{|c|c|c|}
\hline Sustainability Entrepreneurship Tasks & $\begin{array}{l}\text { Sustainability Entrepreneurship Competencies } \\
\text { (Knowledge/Skills/Attitudes) }\end{array}$ & Sustainability Competencies \\
\hline \multirow{3}{*}{$\begin{array}{l}\text { Develops a vision, outlines a business concept } \\
\text { and writes a business plan, guided by the } \\
\text { bounded triple-bottom-line approach } \\
{[25,34,35,38]} \\
\text { Identifies the appropriate sustainable business } \\
\text { structure (corporate form) and procedures (e.g., } \\
\text { sustainability accounting) [1,34] [X] } \\
\text { Identifies financial resources (start-up funds) } \\
\text { and potential impact investors }[25,34] \\
\text { Identifies sustainable (e.g., renewable) local and } \\
\text { regional resources, technologies, equipment, } \\
\text { and transport }[1,34,35] \\
\text { Develops relationships across the supply chain, } \\
\text { with potential customers, and other } \\
\text { stakeholders, with a focus on local and regional } \\
\text { systems }[1,32,40] \\
\text { Challenges profit-maximizing ideologies and } \\
\text { practices }[13] \\
\text { Tests product/service }[50][X]\end{array}$} & $\begin{array}{l}\text { Knowledge of legal norms for cooperative } \\
\text { businesses and benefit corporations (in the U.S.) } \\
{[1,34]} \\
\text { Knowledge of impact investment and other } \\
\text { sustainable funding schemes }[45][X] \\
\text { Knowledge of sustainable business frameworks, } \\
\text { tools, and procedures, e.g., the Sustainable Business } \\
\text { Canvas model }[1,10,26,27,42][X]\end{array}$ & \multirow{3}{*}{$\begin{array}{l}\text { System-thinking competence; } \\
\text { Value-thinking competence; } \\
\text { Future-thinking competence; } \\
\text { Strategic competence; } \\
\text { Interpersonal competence; } \\
\text { Integration competence }\end{array}$} \\
\hline & $\begin{array}{l}\text { Able to think in economic systems such as circular } \\
\text { economy, nexus of social/economic/environmental } \\
\text { systems in relation to business, local and regional } \\
\text { economies, supply chains, the enterprise as a } \\
\text { system }[1,15,40,42] \\
\text { Planning skills [38,39] } \\
\text { Basic math and analytical reasoning skills [39] } \\
\text { Continuous learning skills [29] } \\
\text { Teamworking skills, communication skills, } \\
\text { motivation skills, commitment skills, delegation } \\
\text { skills, coordination skills, ability to compromise } \\
\text { [29,36,44] }\end{array}$ & \\
\hline & $\begin{array}{l}\text { Committed to sharing values and power with } \\
\text { appropriate stakeholders and decision-makers [44] } \\
\text { Reliable and productive [45] }\end{array}$ & \\
\hline
\end{tabular}

Note: $[\mathrm{X}]$ indicates that additions were made to items extracted from the referenced sources or that new items were added.

\subsubsection{Start-Up Phase}

During the start-up phase, sustainability entrepreneurs activate the knowledge base they have built during the previous planning phase with the focus being on launching the enterprise, or, in other words, implementing the business plan (Table 5). This phase is to a large extent about turning know-how-of knowledge into know-how-to knowledge with respect to securing financial resources, business incorporation, business procedures, and so forth. For example, in the previous phase, entrepreneurs have begun to explore alternate social and environmental accounting tools. During this phase, entrepreneurs now use these tools in real-time, continuously learning and adapting to the enterprise's needs. In the planning phase, entrepreneurs have identified potential local or regional suppliers. In the Start-Up phase, entrepreneurs now undertake the task of putting together Memorandums of Understanding (MOUs) and contracts that ensure suppliers are contributing positively to social and ecological communities (for example, suppliers that are fair-trade certified). These tasks require more than just technical skills and some level of experience; they also call for "soft" entrepreneurship skills such as perseverance and tenacity, in particular when mistakes are being made and plan implementation (partially) fails. These attitudes are most productive in conjunction with "people skills". A key resource for a sustainability entrepreneur is the regional and local economy his/her enterprise is embedded in. Demonstrating good partnership behavior, orientation towards the community, and accessibility are critical tasks for building social capital, and they can, if framed openly and honestly, also support marketing and building a loyal consumer base. This requires continuous learning and innovation skills to understand, adjust to, reform, and transform existing structures and relationships within the local/regional economy. As the enterprise is being built, tools such as stakeholder mapping, supply-chain analysis, and impact assessment can help to establish transparent procedures for determining and reporting on suppliers, material used, environmental footprint, and other important aspects of the enterprise. Building the workforce in a sustainability enterprise starts with recruitment that looks beyond qualifications and strives for making positive impacts in the life of people with little opportunity and records of marginalization. Yet, recruitment is 
just the start. It continues with building programs for training and personal advancement, in particular directed towards the unique features of the enterprise such as employee participation, broad value orientation, solidarity, and so forth. Integrative leadership that builds confidence and wellbeing across the workforce is among the many "people skills" (and associated knowledge) that are required during this phase. Last, but not least, the sustainability entrepreneur ought to lead by example also when it comes to self-care and life-work-balance—-tasks that require considerable previous and ongoing practice and skill development.

Table 5. Tasks and competencies in the start-up phase of sustainability entrepreneurship.

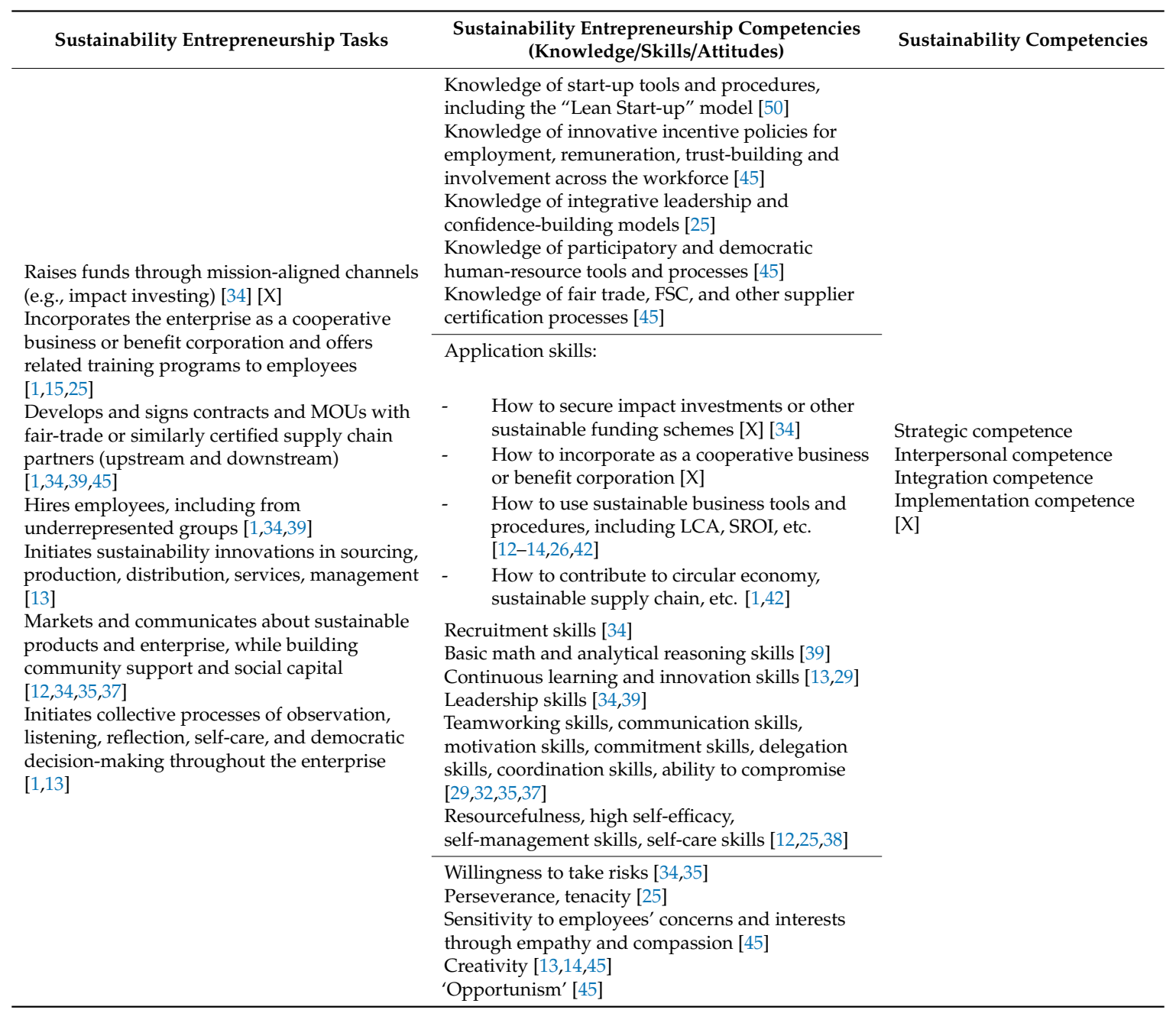

Note: $[\mathrm{X}]$ indicates that additions were made to items extracted from the referenced sources or that new items were added.

\subsubsection{Build-Out Phase}

During the build-out phase, management and steering processes, harvesting collective intelligence and being based on democratic principles, become routine (Table 6). Processes that seemed novel and inconvenient, at times, in the start-up phase, are now regular procedures. Sustainability thinking, tools (such as sustainability accounting), and standards are applied and referenced in all processes of the enterprise. While the previous stage initialized the cycle of observation, listening, reflection, learning, and adjustments across the enterprise, it is now the "normal" mode of operation. All units support comprehensive sustainability reporting. However, there are additional efforts that might have been postponed or left underdeveloped in the start-up phase. Knowledge of participatory and democratic human resources tools acquired in the start-up phase is now activated. While managing 
employees may have followed a more conventional approach in the start-up phase (due to time pressure and other constraints), establishing a positive internal culture of empowerment through gender and cultural equality, fair salaries, family-friendly working hours, health programs, and training programs is a key task for sustainability entrepreneurs in this phase. While entrepreneurs continue to respond to employee concerns and interests, the focus shifts towards building an internal community ("solidarity").

Building out the external relationships with suppliers, customers, and other stakeholders is equally important. All of these processes, even if consolidated in routines, pose challenges and call for a continuous inspiration and motivation, as well as, at times, negotiation and conflict resolution ("people skills"). A key for all of these processes and the enterprise overall to succeed is to avoid drifting into complacency. This is what differentiates start-up entrepreneurs from lasting entrepreneurs-that they preserve and activate their openness to find and cultivate talent from unlikely places, their willingness to learn and take risks, their curiosity and desire to innovate, their leadership that is not afraid of introducing changes as needed, and their perseverance to achieve sustainability goals, even beyond the enterprise. Finally, while entrepreneurs might have been engaged in political advocacy for local business, involvement as a strong partner in the local/regional economy beyond the individual firm (through continuous political efforts and membership in relevant groups) is key in insuring long-term social and economic viability.

Table 6. Tasks and competencies in the build-out phase of sustainability entrepreneurship.

\begin{tabular}{|c|c|c|}
\hline Sustainability Entrepreneurship Tasks & $\begin{array}{l}\text { Sustainability Entrepreneurship Competencies } \\
\text { (Knowledge/Skills/Attitudes) }\end{array}$ & Sustainability Competencies \\
\hline $\begin{array}{l}\text { Collectively and democratically steers, } \\
\text { manages, and adapts enterprise, using } \\
\text { sustainability thinking, tools, and standards as } \\
\text { well as input from all employees [1] } \\
\text { Manages budget and financial performance } \\
\text { from the triple bottom line perspective [1,15,32] } \\
\text { Manages processes of observation, listening, } \\
\text { reflection, learning, and adjustments aligned } \\
\text { with steering processes [1,15,25,39,45] } \\
\text { Evaluates and reports on sustainability } \\
\text { performance (water, energy, materials, } \\
\text { emissions, well-being, etc.) throughout all } \\
\text { operations and the value chain [1,12,15,32,42] } \\
\text { Inspires and motivates workforce and peers, } \\
\text { including conflict resolution [34,35,37] } \\
\text { Supports and empowers workforce through } \\
\text { gender and cultural equality, fair salaries, } \\
\text { family-friendly working hours, health } \\
\text { programs, training programs [1,45] } \\
\text { Serves as a strong partner in the local/regional } \\
\text { economy through political lobbying, advocacy } \\
\text { and membership in local/regional business } \\
\text { associations and groups [1,15,45] }\end{array}$ & $\begin{array}{l}\begin{array}{l}\text { Expansion of conceptual and procedural } \\
\text { knowledge identified in previous phases }\end{array} \\
\text { Application skills: } \\
\text { - } \quad \text { How to use sustainable business tools and } \\
\quad \text { procedures for reporting, assessment, and } \\
\text { accounting [12-14,25,26,42] } \\
\quad \text { How to use participatory and democratic } \\
\quad \text { human resources tools [12,26,45] } \\
\quad \text { How to contribute to circular economy, } \\
\quad \text { sustainable supply chain, etc. [1,42] } \\
\text { Recruitment skills [34] } \\
\text { Basic math and analytical reasoning skills [39] } \\
\text { Continuous learning and innovation skills } \\
\text { [10,29,34,37] } \\
\text { Leadership skills [15,39,40] } \\
\text { Teamworking skills, communication skills, } \\
\text { motivation skills, commitment skills, delegation } \\
\text { skills, coordination skills, ability to compromise } \\
\text { [1,15,26,29,35,37,42,45] } \\
\text { Resourcefulness, high self-efficacy, } \\
\text { self-management skills, self-care skills [12,25,38] } \\
\text { Willingness to take risks [34,35] } \\
\text { Perseverance, tenacity [25] } \\
\text { Self-advocacy [45] } \\
\text { Solidarity [45] }\end{array}$ & $\begin{array}{l}\text { Future-thinking competence } \\
\text { Strategic competence } \\
\text { Interpersonal competence } \\
\text { Integration competence } \\
\text { Implementation competence } \\
{[X]}\end{array}$ \\
\hline
\end{tabular}

Note: $[X]$ indicates that additions were made to items extracted from the referenced sources or that new items were added.

\subsubsection{Consolidation Phase}

During the consolidation phase, sustainability entrepreneurs continue to pursue qualitative growth of their enterprise, managing a bounded triple-bottom line and monitoring all processes identified in the previous phases (Table 7). In stark contrast to carefully protected copyrighted and intellectual property, sustainability entrepreneurs open-source their principles, processes, and experiences through accessible e-commerce and publishing platforms, allowing other entrepreneurs to innovate and transform their own enterprises. As entrepreneurs look to exit their venture, they focus on handing ownership over to 
their employees, rather than selling their firm to the highest bidder. Finally, in addition to continued political advocacy, sustainability entrepreneurs take on mentorship roles, particularly for entrepreneurs from underrepresented groups.

Table 7. Tasks and competencies in the consolidation phase of sustainability entrepreneurship.

\begin{tabular}{|c|c|c|}
\hline $\begin{array}{l}\text { Sustainability Entrepreneurship } \\
\text { Competencies }\end{array}$ & $\begin{array}{c}\text { Sustainability Entrepreneurship } \\
\text { Competencies } \\
\text { (Knowledge/Skills/Attitudes) }\end{array}$ & Sustainability Competencies \\
\hline \multirow{9}{*}{$\begin{array}{l}\text { Advances qualitative growth } \\
\text { including continuous learning and } \\
\text { innovation [1] } \\
\text { Pursues sustainability beyond } \\
\text { boundaries of enterprise (e.g., } \\
\text { political processes) [1] } \\
\text { May exit the venture by handing } \\
\text { over ownership to employees [8] } \\
\text { Makes principles, processes, and } \\
\text { experiences available to other } \\
\text { entrepreneurs through } \\
\text { open-source platforms [X] } \\
\text { Mentors other sustainability } \\
\text { entrepreneurs, in particular from } \\
\text { underrepresented groups [X] } \\
\text { Scales up advocacy and lobbying } \\
\text { activities [45] }\end{array}$} & $\begin{array}{l}\text { Expansion of conceptual and } \\
\text { procedural knowledge identified } \\
\text { in previous phases }\end{array}$ & \multirow{9}{*}{$\begin{array}{l}\text { System-thinking competence; } \\
\text { Value-thinking competence; } \\
\text { Future-thinking competence; } \\
\text { Strategic competence; } \\
\text { Interpersonal competence }\end{array}$} \\
\hline & $\begin{array}{l}\text { Continuous learning and } \\
\text { innovation skills }[10,29,34,37] \\
\text { Leadership skills }[15,39,40]\end{array}$ & \\
\hline & Teamworking skills, & \\
\hline & communication skills, motivation & \\
\hline & skills, commitment skills, & \\
\hline & $\begin{array}{l}\text { delegation skills, coordination } \\
\text { skills, ability to compromise }\end{array}$ & \\
\hline & {$[1,15,29,35-37,41]$} & \\
\hline & $\begin{array}{l}\text { Resourcefulness, high self-efficacy, } \\
\text { self-management skills, self-care } \\
\text { skills }[12,25,38]\end{array}$ & \\
\hline & $\begin{array}{l}\text { Attitude of caring and sharing [45] } \\
\text { Solidarity [45] }\end{array}$ & \\
\hline
\end{tabular}

Note: $[\mathrm{X}]$ indicates that additions were made to items extracted from the referenced sources or that new items were added.

\section{Discussion}

As new business models and practices respond to sustainability challenges around the world, scholars, educators, and practitioners call on universities to educate a new generation of sustainability entrepreneurs [2] (pp. 76-82) $[1,10,11,51]$. Yet, there is a lack of cohesion among the many answers to the question of what competencies this new type of entrepreneur should possess. Much of the literature draws on larger corporations/corporate social responsibility (CSR) initiatives or theoretical considerations $[11,14]$. This literature gives little or no consideration to the changing sustainability entrepreneurship practice, which calls for new competencies. The (re-)emergence of economic and business models, which depart from profit-maximization and adopt a broad set of guiding values, such as employee-owned businesses, benefit corporations, impact investment, and local living economies, to name a few, require different skills for building and running enterprises. In our literature review, only two of the reviewed sources mention such competencies [1,15]. While empirical case studies portrait sustainability entrepreneurs and enterprises [52-54], the framework presented above attempts to map out the underlying competencies needed.

This framework does not completely start over but re-interprets a good share of conventional business competencies for new practices. For example, human resource management, accounting, and marketing provide starting points for sustainability entrepreneurs $[55,56]$, but with very different orientation [40]. Designing employee benefit systems here adopts a bounded triple-bottom-line perspective as opposed to the conventional single- (or double-) bottom line. This requires innovation such as employee-ownership programs, paid family leave, paid volunteer time for employees, etc. Conventional interpersonal communication in business [57] may follow a top-down managerial approach, leaving little space for taking inputs from employees seriously in elicitation and decision making. In sustainability entrepreneurship, democratic governance might face challenges of inefficiency 
or peer-to-peer conflict resolution, but with appropriate skill development [31], these challenges can be mastered.

The framework uses a real-world entrepreneurship process model, which allows for both practice-orientation and integration of competencies, which most competency frameworks struggle with [23]. The process orientation offers insight into how competencies build upon each other over time. For example, during the discovery phase, entrepreneurs need knowledge of sustainable business forms (e.g., structure, function, operations, etc. of employee-owned businesses). As entrepreneurs move on to the planning phase, this knowledge is then activated through best practices (e.g., specific laws governing employee-owned businesses or specific regulations how to legally incorporate as an employee-owned business). Many of the competencies in this framework follow a similar knowledge to the activation pathway along the phases of sustainability entrepreneurship.

While this framework is presented in a linear fashion, sustainability entrepreneurs often move through this process iteratively (as indicated with dashed arrows in Figure 2) and different pathways are viable. Developing a robust business plan in the planning phase might precede securing investments in the start-up phase. However, initial investments might be needed to test products/services in the planning phase. A sustainability entrepreneur might rely on the "Lean Start-up" model and develop a "minimum viable product" using seed funds (impact investment or crowdfunding) in the planning phase and/or the start-up phase [50]. The iterative and variable nature of this process does not change the need for specific competencies. Developing a robust business plan for a sustainable enterprise or rapidly testing a "minimum viable product" are two separate tasks. Yet, they require creativity and planning skills, familiarity of a circular economy, and an attitude of reliability and productivity, among others. Building these competencies ensures sustainability entrepreneurs can successfully and agilely complete a diversity of tasks.

This competencies framework can be used for designing integrated, scaffolded learning pathways in educational programs [58]. On the one hand, courses could focus on one of the phases, and build on each other. For example, an introductory course could focus on the discovery phase and cover the respective tasks and competencies. The next course would use the main tasks of the planning phase as course-level learning objectives and so forth. The detailed lists of related tasks and corresponding competencies help selecting appropriate readings, background material, and hands- on training tools for students. On the other hand, the framework could be used to adopt Brundiers et al.'s [59] progressive competencies training model, by letting students go through all, or most, of the five phases in four progressive stages: bringing the world in, visiting the world, simulating the world, and engaging with the world. In the first stage, students would do a case study on a successful sustainability entrepreneur/enterprise, reconstructing all five phases, maybe inviting the entrepreneur to class to verify the reconstruction. In the second stage, students would spend time with sustainability entrepreneurs in sustainability enterprises and experience the five phases-in glimpses because of time constraints. In the third stage, students would simulate building their own sustainability enterprises-going through all five phases in a protected space. In the final stage (e.g., culminating experience), the students would actually attempt to build their own sustainability enterprises-going through the first three to four phases of the model. This application of the framework would intertwine education and practice of sustainability entrepreneurship as close as possible.

Simultaneously, the framework could be used to develop course-specific assessment tools. Advanced assessment tools can test competence development through in vivo simulation that mirror real-world tasks in each phase. Students in courses that focus on the discovery phase might be asked to defend a local living economy development plan against a mock city council. In the simulation, students might be challenged by conventional business perspectives, e.g., economic development that focuses on attracting "big business" to the city, and asked to defend sustainability entrepreneurship, e.g., economic development that fosters local worker cooperatives and social enterprises in the city. This type of simulation would assess students' knowledge of sustainable business models as well as their skills to challenge profit-maximizing economic development approaches. 


\section{Conclusions}

This study presents a framework of competencies that sustainability entrepreneurs would ideally possess. The framework is based on various strands of literature to link it to the current educational discourses and on a five-phase process model of sustainability entrepreneurship to link it to real-world activities.

The framework is generic and therefore does not capture all context-specific 'materializations' of the compiled competencies. For example, benefit corporations and worker cooperatives as legal business designations are only available in certain states or countries; similarly, certain laws governing particular human resources processes such as employment and benefits. This needs to be accounted for when applying this framework to a specific context. Yet, the framework offers generic guidance on all competencies that might need further specification.

The framework also reflects the current state of entrepreneurship theory and practice. Relatively novel entrepreneurial frameworks such as the "Lean Start-up" model are accounted for, but only exemplarily. Again, as a generic framework, the compiled competencies are open to incorporating entrepreneurial innovations which will only emerge over the coming years. This might eventually require extensions and modifications of the framework, too.

This framework is intended to guide the design of programs and courses in sustainability entrepreneurship as well as their assessment. As the framework is being adopted and applied, there are several additional advancements to pursue. First, the framework would benefit from empirical validation by currently practicing entrepreneurs who are piloting and pioneering sustainability enterprises (employee-owned businesses, benefit corporations, etc.). Empirical research would need to demonstrate for real-world entrepreneurial practice if these are indeed the competencies that enable sustainability entrepreneurs to do their jobs. Second, the framework needs to be constructively aligned with learning-teaching settings and pedagogies that are most suited to convey the competencies of sustainability entrepreneurship. This should not be limited to formal higher education but extend towards business incubators and accelerators. Third, the framework could be advanced through empirical studies on programs and courses that have adopted it-how successful are they in building these competencies? This question needs to be answered with respect to real-world sustainability outcomes rather than through students' self-assessments or examinations.

While advancing the robustness of the framework and its applications, progress towards sustainability through entrepreneurs and enterprises depends on many more influential factors. Education plays a role, but so do many other factors. If a sustainability transformation is to unfold, support for cooperative businesses, benefit corporations, impact investment, local living economies, and so forth needs to also come from progressive law makers, politicians, administrators, advocates, community organizers, and, last but not least, conscious consumers (and it does). What we, as educators, can do is be good collaborators and partners in this endeavor.

Author Contributions: Both authors contributed equally to the research and the writing of the article.

Funding: This research was funded by the Lower Saxony Ministry of Science and Culture \& Volkswagen Foundation through the grant "Educating Future Change Agents-Higher Education as a Motor of the Sustainability Transformation" (A115235) through the program "Science for Sustainable Development".

Acknowledgments: The authors would like to thank their colleagues and/or supervisors Matthias Barth, George Basile, Aaron Redman, Jan-Ole Brandt, Theres Konrad, Jodie Birdman, Jana Timm, and Marie Weiss from Arizona State University (USA) and Leuphana University of Lüneburg (Germany) for support on the research presented in this article and for comments on the manuscript at various stages.

Conflicts of Interest: The authors declare no conflict of interest.

\section{References}

1. Wiek, A.; Foucrier, T.; Basile, G. How to Analyze and Evaluate Enterprises against Principles of Sustainability-Framework and Applications; Working Paper; School of Sustainability, Arizona State University: Tempe, AZ, USA, 2016. 
2. Higley, T. Entrepreneurs and wicked problems. Solutions 2019, 10, 76-82.

3. Cornuel, E.; Hommel, U. Moving beyond the rhetoric of responsible management education. J. Manag. Dev. 2015, 34, 2-15. [CrossRef]

4. Dyllick, T. Responsible management education for a sustainable world: The challenges for business schools. J. Manag. Dev. 2015, 34, 16-33. [CrossRef]

5. Jamali, D.; Abdallah, H.; Matar, F. Opportunities and challenges for CSR mainstreaming in business schools. Int. J. Technol. Educ. Mark. 2016, 6, 1-29. [CrossRef]

6. Snelson-Powell, A.; Grosvold, J.; Millington, A. Business school legitimacy and the challenge of sustainability: A fuzzy set analysis of institutional decoupling. Acad. Manag. Learn. Educ. 2016, 15, 703-723. [CrossRef]

7. Ferns, G. Thinking globally, teaching sustainability: Embedding sustainability in international business studies and addressing student responses. In Incorporating Sustainability in Management Education; Amaeshi, K., Muthuri, J.N., Ogbechie, C., Eds.; Palgrave Macmillan: Cham, Switzerland, 2019; pp. 83-104.

8. Driscoll, C.; Price, S.; McKee, M.; Nicolls, J. An Assessment of Sustainability Integration and Communication in Canadian MBA Programs. J. Acad. Ethics 2017, 15, 93-114. [CrossRef]

9. Starik, M.; Rands, G.P. In search of sustainability in management education. Acad. Manag. Learn. Educ. 2010, 9, 377-383.

10. Hesselbart, C.; Schaltegger, S. Educating change agents for sustainability-Learnings from the first sustainability management master of business administration. J. Clean. Prod. 2014, 62, 24-36. [CrossRef]

11. Lans, T.; Blok, V.; Wesselink, R. Learning apart and together-Towards an integrated competence framework for sustainable entrepreneurship in higher education. J. Clean. Prod. 2014, 62, 37-47. [CrossRef]

12. Osagie, E.; Wesselink, R.; Blok, V.; Lans, T.; Mulder, M. Individual competencies for corporate social responsibility-A literature and practice perspective. J. Bus. Ethics 2016, 135, 233-252. [CrossRef]

13. Mindt, L.; Rieckmann, M. Developing competencies for sustainability-driven entrepreneurship in higher education-A literature review of teaching and learning methods. Teoría. De La Educación 2017, 29, 129-159.

14. Ploum, L.; Blok, V.; Lans, T.; Omta, O. Toward a validated competence framework for sustainable entrepreneurship. Organ. Environ. 2018, 31, 113-132. [CrossRef] [PubMed]

15. Biberhofer, P.; Lintner, C.; Bernhardt, J.; Rieckmann, M. Facilitating work performance of sustainability-driven entrepreneurs through higher education-The relevance of competencies, values, worldviews and opportunities. Int. J. Entrep. Innov. 2018, 20, 21-38. [CrossRef]

16. Baron, R.A.; Shane, S.A. Entrepreneurship: A Process Perspective; Southwest/Thomson: Cincinnati, OH, USA, 2004.

17. Ardichvili, A.; Cardozo, R.; Ray, S. A theory of entrepreneurial opportunity identification and development. J. Bus. Ventur. 2003, 18, 105-123. [CrossRef]

18. Korunka, C.; Frank, H.; Lueger, M.; Mugler, J. The entrepreneurial personality in the context of resources, environment, and the startup process-A configurational approach. Entrep. Theory Pract. 2003, 28, $23-42$. [CrossRef]

19. Choi, Y.R.; Shepherd, D.A. Entrepreneurs' decisions to exploit opportunities. J. Manag. 2004, 30, $377-395$. [CrossRef]

20. Clarysse, B.; Moray, N. A process study of entrepreneurial team formation: The case of a research-based spin-off. J. Bus. Ventur. 2004, 19, 55-79. [CrossRef]

21. Shane, S.; Cable, D. Network ties, reputation, and the financing of new ventures. Manag. Sci. 2002, 48, 364-381. [CrossRef]

22. DeTienne, D.R. Entrepreneurial exit as a critical component of the entrepreneurial process-Theoretical development. J. Bus. Ventur. 2010, 25, 203-215. [CrossRef]

23. Wilhelm, S.; Förster, R.; Zimmermann, A.B. Implementing competence orientation-Towards constructively aligned education for sustainable development in university-level teaching-and-learning. Sustainability 2019, 11, 1891. [CrossRef]

24. Azanza, G.; Grama, S.; Bono, G. Entrepreneurship Education in Business Schools: Best Practices and Recommendations; EQUAL Report; EQUAL: Brussels, Belgium, 2017.

25. Morris, M.H.; Webb, J.W.; Fu, J.; Singhal, S. A Competency-based perspective on entrepreneurship education-Conceptual and empirical insights. J. Small Bus. Manag. 2013, 51, 352-369. [CrossRef]

26. Upward, A.; Jones, P. An ontology for strongly sustainable business models-Defining an enterprise framework compatible with natural and social science. Organ. Environ. 2016, 29, 97-123. [CrossRef] 
27. Basile, G.; Broman, G.I.; Robert, K.H. A systems-based approach to sustainable enterprise: Requirements, utility and limits. In The Business of Sustainability: Trends, Policies, Practices, and Stories of Success, Volume I: Global Challenges and Opportunities; McNall, S.G., Hershauer, J.C., Basile, G., Eds.; Praeger: Santa Barbara, CA, USA, 2011; pp. 3-28.

28. Barth, M. Implementing Sustainability in Higher Education: Learning in an Age of Transformation; Routledge: New York, NY, USA, 2014.

29. Wiek, A.; Withycombe, L.; Redman, C.L. Key competencies in sustainability-A reference framework for academic program development. Sustain. Sci. 2011, 6, 203-218. [CrossRef]

30. Wiek, A.; Withycombe, L.; Redman, C.L.; Banas Mills, S. Moving forward on competence in sustainability research and problem solving. Environ. Sci. Policy Sustain. Dev. 2011, 53, 3-12. [CrossRef]

31. Brundiers, K.; Wiek, A. Beyond interpersonal competence-Teaching and learning professional skills in sustainability. Educ. Sci. 2017, 7, 39. [CrossRef]

32. Willard, M.; Wiedmeyer, C.; Warren Flint, R.; Weedon, J.S.; Woodward, R.; Feldman, I.; Edwards, M. The sustainability professional-2010 competency survey report. Environ. Qual. Manag. 2010, 20, 49-83. [CrossRef]

33. Schaltegger, S.; Wagner, M. Sustainable entrepreneurship and sustainability innovation-Categories and interactions. Bus. Strategy Environ. 2011, 20, 222-237. [CrossRef]

34. Chell, E.; Karatas-Ozkan, M.; Nicolopoulou, K. Social entrepreneurship education-Policy, core themes and developmental competencies. Int. J. Entrep. Educ. 2007, 5, 282.

35. Miller, T.L.; Wesley, C.L.; Williams, D.E. Educating the minds of caring hearts-Comparing the views of practitioners and educators on the importance of social entrepreneurship competencies. Acad. Manag. Learn. Educ. 2012, 11, 349-370. [CrossRef]

36. Fantini, A.; Arias-Galicia, F.; Guay, D. Globalization and 21st Century Competencies—Challenges for North American Higher Education; Working Paper; (Publication Number 2A343); Consortium for North America Higher Education Collaboration: Boulder, CO, USA, 2001.

37. Salgado, P.; Abbott, D.; Wilson, G. Dimensions of professional competences for interventions towards sustainability. Sustain. Sci. 2018, 13, 163-177. [CrossRef]

38. Lans, T.; Verstegen, J.; Mulder, M. Analysing, pursuing and networking-A validated three-factor framework for entrepreneurial competence from a small business perspective. Int. Small Bus. J. 2011, 29, 695-713. [CrossRef]

39. Mitchelmore, S.; Rowley, J. Entrepreneurial competencies-A literature review and development agenda. Int. J. Entrep. Behav. Res. 2010, 16, 92-111. [CrossRef]

40. Lambrechts, W.; Mulaà, I.; Ceulemans, K.; Molderez, I.; Gaeremynck, V. The integration of competences for sustainable development in higher education-Analysis of bachelor programs in management. J. Clean. Prod. 2013, 48, 65-73. [CrossRef]

41. Wu, W.W. A competency-based model for the success of an entrepreneurial start-up. WSEAS Trans. Bus. Econ. 2009, 6, 279-291.

42. Bernhardt, J.; Elsen, S.; Lintner, C.; Boman, J. Summary CASE Needs Analysis: Findings on Competencies for Sustainability-Driven Entrepreneurship; Working Paper; CASE (Competencies for a Sustainable Socio-Economic Development): Vienna, Austria, 2015.

43. Afshar Jahanshashi, A.; Brem, A.; Bhattacharjee, A. Who takes more sustainability-oriented entrepreneurial actions? The role of entrepreneurs' values, beliefs, and orientations. Sustainability 2017, 9, 1636. [CrossRef]

44. Waldron, T. How social entrepreneurs facilitate the adoption of new industry practices. J. Manag. Stud. 2016, 53, 821-845. [CrossRef]

45. Moreau, C.; Mertens, S. Managers' competences in social enterprises: Which specificities? Soc. Enterp. J. 2013, 9, 164-183. [CrossRef]

46. Belz, F.M.; Binder, J.K. Sustainable entrepreneurship: A convergent process model. Bus. Strategy Environ. 2015, 26, 1-17. [CrossRef]

47. Shane, S.; Venkataraman, S. The promise of entrepreneurship as a field of research. Acad. Manag. Rev. 2000, 25, 217-226. [CrossRef]

48. Corner, P.; Ho, M. How opportunities develop in social entrepreneurship. Entrep. Theory Pract. 2010, 34, 635-659. [CrossRef] 
49. Kuckertz, A.; Wagner, M. The influence of sustainability orientation on entrepreneurial intentions-Investigating the role of business experience. J. Bus. Ventur. 2010, 25, 524-539. [CrossRef]

50. Blank, S. Why the lean start-up changes everything. Harv. Bus. Rev. 2013, 91, 63-72.

51. Lourenco, F.; Jones, O.; Jayawarna, D. Promoting sustainable development-The role of entrepreneurship education. Int. Small Bus. J. Res. Entrep. 2013, 31, 841-865. [CrossRef]

52. Majee, W.; Hoyt, A. Building community trust through cooperatives-A case study of a worker-owned homecare cooperative. J. Community Pract. 2009, 4, 444-463. [CrossRef]

53. Basu, A.; Osland, A.; Solt, M. A new course on sustainability entrepreneurship. In Proceedings of the VentureWell's OPEN Conference, Pisa, Italy, 3-5 October 2011; National Collegiate Inventors \& Innovators Alliance: Hadley, MA, USA, 2011.

54. Rodgers, C. Sustainable entrepreneurship in SMEs-A case study analysis. Corp. Soc. Responsib. Environ. Manag. 2010, 17, 125-132. [CrossRef]

55. Ulrich, D.; Brockbank, W.; Johnson, D.; Younger, J. Human resource competencies—Responding to increased expectations. Employ. Relat. Today 2007, 34, 1-12. [CrossRef]

56. Ulrich, D.; Brockbank, W.; Yeung, A.; Lake, D. Human resource competencies: An empirical assessment. Hum. Resour. Manag. 1995, 34, 473-495. [CrossRef]

57. Lewrich, M.; Omar, M.; Raeside, R.; Sailer, K. Education for entrepreneurship and innovation-Management capabilities for sustainable growth and success. World J. Entrep. Manag. Sustain. Dev. 2010,6,1-18. [CrossRef]

58. Collins, A.; Brown, J.S.; Holum, A. Cognitive apprenticeship-Making thinking visible. Am. Educ. 1991, 15, 6-11.

59. Brundiers, K.; Wiek, A.; Redman, C. Real-world learning opportunities in sustainability—From classroom into the real-world. Int. J. Sustain. High. Educ. 2010, 11, 308-324. [CrossRef]

(C) 2019 by the authors. Licensee MDPI, Basel, Switzerland. This article is an open access article distributed under the terms and conditions of the Creative Commons Attribution (CC BY) license (http://creativecommons.org/licenses/by/4.0/). 